FEDERAL RESERVE BANK OF SAN FRANCISCO

WORKING PAPER SERIES

\title{
FDI effects on the labor market of host countries
}

\author{
Galina Hale \\ Federal Reserve Bank of San Francisco \\ Mingzhi Xu \\ University of California, Davis
}

September 2016

Working Paper 2016-25

http://www.frbsf.org/economic-research/publications/working-papers/wp2016-25.pdf

\section{Suggested citation:}

Hale, Galina, Mingzhi Xu. 2016. “FDI effects on the labor market of host countries” Federal Reserve Bank of San Francisco Working Paper 2016-25. http://www.frbsf.org/economicresearch/publications/working-papers/wp2016-25.pdf

The views in this paper are solely the responsibility of the authors and should not be interpreted as reflecting the views of the Federal Reserve Bank of San Francisco or the Board of Governors of the Federal Reserve System. 


\title{
FDI effects on the labor market of host countries
}

\author{
Galina Hale * \\ Federal Reserve Bank of San Francisco \\ Mingzhi Xu \\ University of California, Davis
}

September 21, 2016

\section{Introduction}

Unprecedented growth in global foreign direct investment (FDI) in the last decades is causing dramatic changes in labor markets for both developed and developing countries. FDI brings capital and technology to target firms, industries, and locations, affecting demand for labor and therefore labor force composition, employment, average productivity, wage levels, and wage inequality. In this paper we study these effects, focusing exclusively on the host country. The existing composition of the labor force in the host country is important in determining what kind of labor market effects we observe. Since this composition is quite different for developed and developing countries, so are the labor market effects. Thus, much of our analysis will differentiate between developed and developing host economies.

We distinguish between direct effects on target firms and industries and spillover effects. This distinction is an important one. While direct effects of FDI on target firms are fully internalized

*Corresponding author: galina.b.hale@sf.frb.org. This paper was prepared as an entry to the Handbook on Foreign Direct Investments. Anita Todd helped prepare the draft. The views expressed here are those of the authors and not necessarily those of the Federal Reserve Bank of San Francisco or the Federal Reserve System. 
by foreign investors and are, in most cases, a product of their decision-making, spillover effects on domestic firms are an externality and may warrant policy interventions to attract FDI if the externality is positive, or deter them, if the externality is negative.

We find an impressive amount of consensus in the empirical literature in terms of the direct effects of FDI on labor markets. Almost universally, findings point to FDI leading to higher wages, higher productivity, and increased wage inequality, mostly due to an increase in the skill premium, which is the difference between wages of skilled and unskilled workers. In addition, for developing countries, the literature tends to find a positive effect of FDI on employment, while for advanced economies the effect on employment is more mixed. In terms of spillover effects, the literature provides mixed evidence on the spillover effects of FDI as discussed in Moran (2006). We show that, in terms of labor

market spillovers, there is also quite a bit of consensus: Evidence points consistently to increased wages and productivity in domestic firms as a result of FDI in the same industry. The spillover effect of FDI on other industries' labor markets is yet to be fully researched.

The findings of the literature are broadly consistent with the idea that FDI expands the production set of the economy toward more sophisticated goods or introduces more advanced technology, thereby increasing the demand for skilled labor. This results in higher overall labor demand, higher wages for skilled labor, leading to a higher skill premium and increased average wages, and higher labor productivity. These effects are especially large in countries where skilled labor is scarce and the technological gap is substantial.

In this paper we first review the empirical literature and discuss the mechanisms by which FDI affects host country labor markets and then present a stylized model that illustrates these mechanisms.

\section{Meta-analysis of empirical literature}

There is a large empirical literature on the effects of FDI on local economies, with much of it focused on technology transfers and spillovers. A smaller but still substantial body of literature addresses 
the effects of FDI on a destination country's labor markets, primarily on wages and employment. We begin by summarizing the results of these studies.

We surveyed 30 papers published in academic journals between 1995 and 2015 that empirically analyze the effects of FDI on various aspects of labor markets. These papers vary in many aspects: FDI measures employed, level of aggregation, outcome variables considered, econometric methodologies, and time and country samples. We find that estimates of the effects of FDI on labor markets do not vary systematically across different measures of FDI but do vary across regions. Table 1 summarizes empirical results for various outcomes for advanced and developing economies separately. There are three reasons to separate advanced and developing economies: differences in the existing skill composition of the labor force, different motives driving FDI, and the technological gap between source and destination countries is substantially larger for North-South FDI. All three aspects can result in potentially different effects on labor markets.

Table 1: Summary of the empirical results in the literature: Effects of FDI on labor market outcomes

\begin{tabular}{lcc}
\hline \hline & & \\
& Advanced & Developing \\
\hline & & \\
Employment & $42 / 13 / 15$ & $32 / 19 / 5$ \\
Wage & $81 / 61 / 7$ & $88 / 73 / 6$ \\
Productivity & $9 / 2 / 2$ & $11 / 11 / 0$ \\
Inequality & $47 / 35 / 10$ & $42 / 31 / 6$ \\
\hline \hline
\end{tabular}

Number of studies / Number of positive significant coefficients / Number of negative significant coefficients

We see that the majority of studies focus on wages, employment, and inequality, and pay equal attention to advanced and developing host countries. We observe that with a few exceptions which we will discuss separately, the literature finds that FDI leads to higher wages in both advanced and developing host economies. For developing economies, the literature also finds an overwhelmingly positive effect on total employment and productivity, while the effects on these outcomes for advanced economies are mixed. Finally, more studies find that FDI leads to an increase in inequality than a decline. Obviously, these labor market outcomes are interrelated, and we will discuss the channels 
through which FDI affects the labor market as implied by these results in the rest of this paper.

One important dimension in which FDI studies differ is the level of aggregation and the set of industries, regions, or firms analyzed within the host country. These differences result in different types of FDI effects that can be identified. WHile aggregate analysis (at country, region, or industry level) is good at capturing overall effects, it can only measure the total effect of FDI on the unit of observation, without being able to distinguish between direct effects on target firms and spillover effects on firms that are either competing with or are in upstream or downstream industries relative to target firms. Firm-level or industry/region-level studies are generally able to identify direct and spillover effects separately, but might not be able to measure the magnitude of the overall FDI impact. Table 2 shows the breakdown of the literature and the findings across these three categories: direct effects, spillover effects, and total (or aggregate) effects.

Table 2: Effects of FDI on labor market outcomes by study type

\begin{tabular}{|c|c|c|c|c|c|c|}
\hline & \multicolumn{2}{|c|}{ Direct effect } & \multicolumn{2}{|c|}{ Spillover } & \multicolumn{2}{|c|}{ Aggregate (total) } \\
\hline & Advanced & Developing & Advanced & Developing & Advanced & Developing \\
\hline Employment & $42 / 13 / 15$ & $32 / 19 / 5$ & N.A. & N.A. & N.A. & N.A. \\
\hline Wage & $71 / 58 / 4$ & $49 / 47 / 0$ & $7 / 1 / 3$ & $32 / 22 / 6$ & $3 / 2 / 0$ & $4 / 4 / 0$ \\
\hline Productivity & $6 / 2 / 0$ & $4 / 4 / 0$ & $3 / 0 / 2$ & $7 / 7 / 0$ & N.A. & N.A. \\
\hline Inequality & $6 / 6 / 0$ & $2 / 2 / 0$ & N.A. & N.A. & $41 / 29 / 10$ & $40 / 29 / 6$ \\
\hline
\end{tabular}

Number of studies / Number of positive significant coefficients / Number of negative significant coefficients. N.A. indicates no studies.

We observe that studies of employment effects focus exclusively on the employment of target firms or industries, without measuring any spillover effects. This is understandable, as it would be hard to isolate changes in employment that are driven by FDI in other firms or industries. For target firms, the literature finds that employment might go up or down in advanced economies, while in developing economies the direct effect on employment in target firms is overwhelmingly positive. This is consistent with the idea that FDI improves productivity for developing countries' firms and, because of the market structure, higher productivity tends to be associated with larger firm size, 
leading to an increase in employment. Indeed, all four regressions that tested for direct effects of FDI on labor productivity for developing countries found an increase. In contrast, only two out of six regressions testing for direct effect on labor productivity for advanced economies yielded a positive effect.

Most micro-level studies focus on the effect of FDI on wages. We observe from Table 2 that direct effects, indirect effects, and aggregate effects are overwhelmingly positive for wages. Particularly striking are the results of the meta-analysis of the direct effect of FDI on wages - out of 49 regressions measuring such effects in the papers we analyzed, 47 found positive and statistically significant relationship. Of course, this positive relationship might not be causal, as foreign investors might be cherry-picking firms with higher productivity and higher wages. However, a number of papers that we analyzed address this identification problem using instrumental variables and other approaches and still find positive and statistically significant effects. More unexpected, perhaps, is the spillover effect found in the literature for developing countries. Out of 32 regressions testing for the effect of FDI on wages of domestically owned firms in developing countries, 22 found a positive and statistically significant effect. Some of this effect is likely due to positive productivity spillovers that were found in seven out of seven regressions that tested this hypothesis for developing economies.

Most studies of the effect of FDI on inequality are conducted at the aggregate level, thus measuring total effects. In a few studies that focused on direct effects, all found that an increase in foreign investment increases wage dispersion in target firms or industries and the effect is statistically significant, for both developing and advanced economies.

These results establish the consensus findings in the empirical literature. Before we turn to the discussion of the mechanisms underlying these findings, it is important to highlight some methodological considerations that arise in empirical studies of FDI effects on labor market outcomes. 


\section{Methodological considerations}

There are three main considerations to keep in mind when studying the effects of FDI on any outcome: aggregation level, identification of causality, and proper calculation of standard errors. Here we will discuss them as they apply to empirical studies of the effects of FDI on labor market outcomes.

\subsection{Aggregation level}

With the exception of inequality, which is usually measured as an aggregate, country-wide concept, other labor market outcomes could apply at various levels of aggregation. For instance, the impact on employment can be observed at the level of a firm (number of employees), industry (size or unemployment rate), region (unemployment rate), or country (unemployment rate). Similarly, wages and labor productivity can be measured at any level of aggregation, from worker type within a firm to region, industry, and country. While data availability is frequently a constraint, one has to be mindful of what questions could be answered for a given level of aggregation of the data.

As mentioned earlier, foreign capital targets specific firms in specific industries and locations. Thus, any analysis that is not conducted at a firm level will yield aggregate effects of FDI on the wage, employment, or productivity in the unit of the analysis, without being able to distinguish between direct effects of FDI (that is, effects on target firms) and spillover effects on domestic firms. Aggregate effects are still of interest, but one needs to be careful interpreting the results to avoid implying either direct or spillover channels.

\subsection{Identification of causality}

Regardless of the level of aggregation, but especially with firm-level data, the identification of causal effects of FDI is always a challenge for empirical studies. Not all studies we reviewed are able to identify causal effects, but some are. The challenge arises from the fact that the distribution of FDI is not random across firms, industries, regions, and countries.

Of particular concern is the fact that foreign investors seek to acquire or invest in firms that 
they view as having high growth and profitability potential. The research that investors conduct on potential targets goes well beyond the variables observed by an econometrician, making it impossible to directly control for future growth and profitability potential that investors evaluate. Given that investors carefully evaluate firms' future prospects, the difference between pre- and post- foreign investment metrics cannot be attributed to the effects of FDI, but might instead reflect the selection by foreign investors. This phenomenon is referred to in the literature as a "cherry-picking effect": Foreign investors cherry-pick firms that would be more productive regardless of foreign investment, creating positive correlation between FDI and post-FDI firm productivity without actually having any causal effect. The problem of cherry-picking extends to labor market effects of FDI, because firms that are more productive also tend to have higher wages and grow faster in size relative to their peers.

The cherry-picking problem persists at a more aggregate level — if industries, regions, or countries with faster growing firms are more likely to attract FDI, it would appear to an econometrician that these industries, regions or countries have higher employment and wages than others because of FDI, even if FDI does not actually have any impact. The problem is somewhat mitigated for the firmlevel analysis of spillover effects, where the subject of the analysis are domestic firms. In this case, however, the problem still arises because FDI cannot be measured at the firm level for the purposes of spillover analysis. For example, if the FDI measure is a share of foreign capital in total capital of the firms in a given industry and given location, it could be the case that firms in this industry and location are particularly fast growing for some other reason, and therefore more likely to attract foreign investors. If foreign capital is scarce, firms that are as productive as the ones chosen by foreigners may remain fully domestic. In this case, we would observe a positive correlation between FDI presence in the given region and industry and productivity of domestic firms whether or not FDI has any causal effect.

Among the studies we analyzed, a few tackled the identification problem with instrumental variables (IV) analysis. The goal of these studies was to identify variation in the FDI measure that is not due to expected growth prospects of the firm and use this variation to measure the impact of the 
fully exogenous portion of FDI. For example, Hale and Long (2011) study spillover effects of FDI in a given city and industry on domestic firms' wages in China. To instrument for FDI, they use the fact that access to domestic markets and production for exports are among the main reasons behind foreign investment into Chinese firms as shown in Cheng and Kwan (2000) and Sun et al. (2002). ${ }^{1}$ Thus, they use two instruments: transportation costs in a given industry interacted with the sum of the population of the provinces weighted by the inverse distance to a given city, and the share of firms that export in a given industry and given year interacted with the berth capacity of the port in a given city. These measures are uncorrelated with the wage, are exogenous to specific firms, and are highly correlated with FDI, thus providing exogenous variation that could be explored to identify causal effects of FDI on wages.

Other instruments used in the literature studying labor market effects of FDI relate to other determinants of FDI. Sune et al. (2009) instrument for FDI with foreign R\&D expenditures, which could be proxied by regional-level import intensity, the share of patent applications, and the share of science and technology funding provided by the government and foreign partners. Chen et al. (2011), Wu and Hsu (2012), and Lin et al. (2013) follow the research on trade openness and use geographic variables such as regional market size, population, distance to the equator (latitude), and government FDI policy to instrument for FDI. Aitken et al. (1996) point out that a major motivation of foreign investment is to avoid high labor cost at home; thus, they use the average wage rate of the home country as an instrument for FDI. Finally, Taylor and Driffield (2005), Waldkirch and Nunnenkamp (2009), and Figini and GöRg (2011) use lagged values of FDI as instruments.

Besides the instrumental variables approach, some research has used a propensity score matching technique to resolve the identification problem in the studies of labor market effects of FDI. This method is employed by Huttunen (2007), Girma and Görg (2007), Dinga and Mnich (2010), Bandick and Karpaty (2011), Hijzen et al. (2013), and Peluffo (2015). This approach attempts to create a pseudo experiment in which firms with foreign investment (treatment group) are matched with otherwise identical firms without foreign investment (control group). Differences in outcomes between

\footnotetext{
${ }^{1}$ Similar IVs were also used by Feenstra and Hanson (1997).
} 
the two groups can then be attributed to the causal effect of FDI. Of course, the reliability of this analysis hinges on the ability to identify a properly matched control group. The propensity score matching method can be regarded as a special case of the instrumental variable approach, where the instruments are constructed as the probability of a firm receiving foreign investment. However, unlike standard IV analysis, exclusion restrictions are less stringent for the propensity score matching, resulting in the growing popularity of this method.

\subsection{Attenuation of standard errors}

One more issue that arises specifically in the studies of spillover effects is attenuation of standard errors in cases when the object of the analysis is a firm, but the measure of FDI is aggregate. Because in this case the explanatory variable values are correlated across observations (literally the same for groups of observations), standard errors on this variable are biased downward (Moulton, 1990). Failure to correct for this bias leads to erroneous conclusions regarding the significance of the effects. Fortunately, an easy solution exists for this problem - standard errors need to be clustered at the same level as the level of aggregation of the FDI variable. Most statistical packages now include standard error clustering options, including two-way clustering.

\section{Mechanisms}

To understand overall effects of FDI on wages of the host country, one needs to think about four sets of firms: FDI recipient (target) firms; competing domestic firms that are in the same industry (target industry) as target firms; firms supplying inputs to the target industry (upstream firms); and firms using the output of the target industry as inputs (downstream firms). As we discuss the effects on wages, we will also incorporate evidence on employment and the skill premium (which is reflected in inequality) to distinguish between different channels. 


\subsection{Target firms}

The mechanism of the wage effects on target firms is multifaceted. In its simplest form one can think of FDI increasing the capital-labor ratio of target firms and therefore increasing labor productivity and wages. However, additional factors are frequently at play. FDI is likely to bring along superior technology, especially in cases when foreign investments come from more technologically advanced countries. Superior technology not only raises TFP and labor productivity, but also tends to shift labor composition away from less skilled to more skilled labor. Since skilled labor tends to be better compensated, this shift increases the average wage simply as a composition effect. Moreover, if the labor supply in general and supply of skilled labor in particular are constrained, equilibrium wages are likely to rise on average and the skill premium is likely to increase.

All these mechanisms unambiguously imply an increase in wages in target firms as a result of foreign investment. Thus, even though FDI frequently is attracted by relatively low wages (Braconier, Norback, and Urban (2005)), we would expect wages to rise in the firms acquired by or invested in by foreign capital. The only potential offsetting force is that more advanced technology may require overall less labor, therefore leading to a decline in overall labor demand and therefore lower wages, at least of production workers. In the data, however, this mechanism, if present, is completely overwhelmed by the others - only two studies we surveyed showed a significant negative effect of FDI on wages of target firms. Heyman et al. (2007) study FDI effects on individual workers' wages in Swedish firms in the 1990s and find that foreign takeovers sometimes can lower wages, however, only one specification shows a negative effect, and the paper shows that on average acquired firm's wages increase slightly. In a study of Portuguese firms in the 1990s, Almeida (2007) argues that the positive effect on wages is very small and wage differences between foreign-invested and domestic firms is due to cherry-picking effects. However, even in this study negative significant coefficients are found in only 3 out of 24 specifications of the effect of FDI on wages.

Overall, out of 30 studies we analyzed, which included a total of 169 regression specifications for wages, 134 specifications show that wages increase in target firms as a result of the FDI (see Table 
1). Most of the estimates we reviewed are statistically significant. ${ }^{2}$ As discussed previously, this increase can be due to higher productivity, an increased skill premium and share of skilled workers, or increased competition for labor input.

A closer review of the literature reveals that both increased productivity and an increased skill premium are likely mechanisms that lead to increased wages. All studies we analyzed find increased productivity in target firms, even controlling for cherry-picking selection bias. ${ }^{3}$ Other papers show that both the share of skilled labor and the relative wages of skilled to unskilled workers, the skill premium, increase in target firms. ${ }^{4}$ The latter could be the result of a less elastic supply of skilled labor because it takes time for workers to be trained (Hale and Long, 2011).

Among the estimates of the employment effects of FDI on target firms in the studies we surveyed, about half find positive effects and half find adverse effects for advanced economies. In the study of Central and Eastern European countries, Jude and Silaghi (2015) find that FDI lead to creative job destruction in the labor market through competitive pressure and the introduction of labor-

\footnotetext{
${ }^{2}$ Surveyed literature on wages in foreign-invested enterprises is summarized as follows. Aitken et al. (1996) finds that higher FDI is associated with higher wages in foreign-invested firms; Almeida (2007) and Heyman et al. (2007) find no effects for Sweden and Portugal, as mentioned previously; Conyon et al. (2002) and Girma and Görg (2007) find some positive effects for unskilled wages in the UK; Lipsey and Sjöholm (2004a), Lipsey and Sjöholm (2004b), Harrison et al. (2005) and Sjöholm and Lipsey (2006) find positive effects of FDI on wages for Indonesia; Huttunen (2007) and Hale and Long (2011) both find that FDI imposes an upward pressure on wages that is stronger for skilled workers in China and Finland, respectively; Girma and Görg (2007) finds the effects of FDI on wages are heterogeneous, depending on the originality of the foreign investment; and Conyon et al. (2002) attributes the positive wage effects of FDI to labor's productivity improvement.

${ }^{3}$ Studies that control for FDI selection bias include Feenstra and Hanson (1997), Conyon et al. (2002), Sjöholm and Lipsey (2006), Almeida (2007), Heyman et al. (2007), Girma and Görg (2007), Huttunen (2007), Chen et al. (2011), Hale and Long (2011) and Peluffo (2015).

${ }^{4}$ Investigating Sweden manufacturing data of the 1990s, Bandick and Karpaty (2011) find that the employment effects of foreign acquisitions are stronger for skilled labor. Hijzen et al. (2013) find employment growth after the foreign acquisition is mainly due to the growth of high-skilled jobs. Using Uruguay data, Peluffo (2015) finds that the higher return to skills and the relative demand for skilled labor are mostly due to the productivity enhancement of skilled labor. Using panel data of UK firms, Driffield and Taylor (2000) and Taylor and Driffield (2005) find that most of the increase in inequality arises from the employment and wage changes, moving towards skilled labor. Similar outcomes are found in the research by Figini and Görg (1999) using Ireland data, Aitken et al. (1996) in Mexico and Venezuela,Lipsey and Sjöholm (2004a) and Harrison et al. (2005) in Indonesia. In the case of China, Hale and Long (2011) find an upward pressure from the presence of FDI on skilled workers' wages through increased demand for skilled labor. In the study of Mexican firms in 1997, Feenstra and Hanson (1997) find an increase in skilled labor share. Huttunen (2007), however, finds a decrease in the share of educated workers in target firms in Finland in the 1990s, while Blonigen and Slaughter (2001) find no increase in demand for skilled labor due to inward FDI into the U.S. Using Portuguese data, Almeida (2007) finds that foreign acquirers "cherry pick" domestic firms and have small effects on human capital and average wages of acquired firms. Using UK establishments data, Girma and Görg (2007) find a wage effect on skilled labor is not unambiguously positive but depends crucially on the origin of foreign investment.
} 
saving technology. In the cross-country studies, Hijzen et al. (2013) also find that foreign takeovers are associated with the fall in employment in Germany and the UK, although this effect is not significant. At the other end of the spectrum, Dinga and Mnich (2010) find, using Czech data, that FDI contributes to the improvement of the local labor market by increasing the employment rate and reducing the level of unemployment. In the study of Swedish manufacturing data, Bandick and Karpaty (2011) also confirm the positive employment effect of FDI and find that this effect is stronger for skilled labor. Similarly, using matched employer-employee data for Portugal, Almeida (2007) finds that employment increases following foreign acquisition. Overall, studies of developed countries indicate that while FDI may decrease the number of jobs in the short run by introducing labor-saving technology, it increases job growth in the long term by enhancing labor productivity. Moreover, the positive employment effect is stronger for the skilled workforce due to skill-biased technology transfer.

For developing economies, the majority of the papers we analyzed find a positive effect on employment. In the study of China, Sune et al. (2009) attribute the positive effect of FDI on employment to the high survival rate of firms that receive foreign investment. Using Mexican manufacturing data, Waldkirch and Nunnenkamp (2009) find a significantly positive employment effect of FDI that applies to both the skilled and unskilled workforce, with stronger effects in export-oriented industries. Peluffo (2015) also confirm that FDI increases employment in the study of Uruguay. These results support the hypothesis of competition for labor driving wage increases, even though some find negative impacts of FDI on employment. ${ }^{5}$

To summarize, there is overwhelming evidence of the positive effect of FDI on wages of target firms. Evidence suggests that this positive effect is likely due to all channels discussed: increased productivity, a shift to more skilled composition of labor in target firms, and increased demand for skilled labor and resulting labor market pressure. Employee-level studies caution us, however, against erroneously concluding that each worker is likely to benefit from foreign investment. Composition

\footnotetext{
${ }^{5}$ In the study of China's manufacturing data, Sune et al. (2009) find that foreign ownership does not in itself increase job growth. Instead, high job growth rates of these foreign-invested firms are due to some other firm characteristics such as productivity.
} 
effects mean that some workers may see their wages fall, while others may be laid off. In fact, a substantial fraction of studies shows decreased employment in target firms after acquisition, especially in developed countries.

\subsection{Competing firms}

Among domestic firms most likely affected by FDI are those in target industries and in the same geographical location as target firms. This is because FDI increases demand for all factors of production, including labor. We have seen that, for developing countries especially, employment in target firms tends to increase as a result of FDI. Moreover, due to its greater reliance on skill-complementary technology, a larger foreign presence in the region and industry would lead to a higher demand for skilled labor. Given that the supply of skilled labor is very inelastic in the short and medium run, this would push up the wages of skilled workers in the city and industry with higher FDI presence. Furthermore, with foreign firms attaching greater value to skilled labor (due to their technology with higher skill-complementarity), they will compete away skilled labor with the highest ability, leading to lower quality of skilled labor in domestic firms. This effect is likely to be more prominent for developing countries because of a larger technological gap between domestic and foreign-invested firms.

In addition to these effects stemming from limited labor supply, especially for skilled labor, there might be an increase in wages in the competing firms if technological spillovers from FDI to domestic firms occur. Such spillovers are likely to take the form of skill-biased technological transfer (Feenstra and Hanson (1997), Figini and Görg (1999), Lipsey and Sjöholm (2004a), Bandick and Karpaty (2011), Hale and Long (2011), Driffield and Taylor (2000) and Driffield and Taylor (2000)), thus disproportionately increasing skilled wage.

Indeed, the spillover effect is generally positive for developing countries. Among the 32 estimates of the effect of FDI on wages in competing firms, 22 estimates find a positive spillover effect and only 6 find a negative effect (see Table 2). In particular, Feenstra and Hanson (1997) find positive spillovers of FDI on skilled wages in Mexico, while Hale and Long (2011) find the same for China. For 
the advanced economies, FDI spillovers are more ambiguous than for developing countries. Among the only seven regressions that dealt with this question for advanced economies in the studies we reviewed, only one showed positive significant effect, while in three the effect was negative and significant. A study by Barry et al. (2005) on large Irish firms finds that the labor market spillover effects vary for exporting and non-exporting firms. In particular, FDI may impose a negative effect on the wages and productivity for domestic exporting firms by poaching their best workers without affecting non-exporting firms. ${ }^{6}$ In contrast, Aitken et al. (1996) find no evidence of wage spillovers in Mexican and Venezuelan firms but find that a larger share of foreign firms' employment leads to higher average wages and higher wages for domestic firms in the United States.

The fact that wage spillovers are more likely to be positive for developing countries suggests the importance of technological gaps and limited supply of skilled labor. Thus, evidence is consistent with both, labor market competition effects of FDI on competing firms' wages and skillbiased technology transfer. Indeed, for developing economies, there is evidence of productivity spillovers to competing firms.

\subsection{Vertical spillovers}

Two more sets of domestic firms are likely to be affected by FDI: upstream firms that supply intermediate inputs to foreign-invested firms, and downstream firms that use output of foreign-invested firms as intermediate inputs. The impact on wages of these firms, and more generally on the industries that are upstream and downstream from the target industries, is less obvious.

In some cases, there are positive technological spillovers from FDI to upstream industries, in which case the increased skill premium and increased share of skilled labor will push up the average wage. Labor market competition effects, however, are less likely to be present, especially for skilled labor, due to the probable specialization of the skill set. Furthermore, since FDI tends to increase production in target industries, it is likely to lead to an increased demand for the output of upstream firms,

\footnotetext{
${ }^{6}$ Barry et al. (2005) find that the heterogeneous effects are attributed to the difference in labor market structure faced by exporting and non-exporting firms. Specifically, the authors assume the labor supply is elastic for exporting firms and is inelastic for non-exporting firms.
} 
leading in turn to increased demand for labor in these industries and therefore increased wages. On the other hand, target firms might switch from domestic to foreign suppliers of intermediate inputs, in which case production, labor demand, and wages of upstream industries will decline. Thus, the overall effect of FDI on upstream firms' wages is ambiguous. If it is found to be positive, it is likely to be associated with a higher skill premium, increased employment, or both.

For downstream industries, diversion is likely to be the most dominant factor. Going back to reasons for FDI, we know that for intermediate product industries the most common reason for FDI is export of final goods. If this is the case, domestic downstream firms are likely to experience an increase in the cost of intermediate inputs, leading to lower production, lower employment, and therefore lower wages.

Unfortunately, studies of vertical spillovers of FDI to labor market outcomes are very scarce. In the only study we uncovered that addresses this question explicitly, Pittiglio et al. (2015) study FDI impact on Italian firms and find that the effect on wages for both upstream and downstream industries is negative. More studies are needed, however, before one can fully understand the impact of FDI on labor in upstream and downstream industries.

\section{$5 \quad$ Stylized model}

The empirical findings summarized and analyzed in this paper point to a few regularities. First, wages in host countries tend to increase as a result of FDI, although not necessarily for everybody. Second, the impact on employment is uneven - employment of skilled workers tends to increase more than employment of unskilled workers, which may even decrease. Third, skill premiums and average labor productivity tend to increase as a result of FDI, leading to increased wage inequality, especially in developing countries. These effects are observed on aggregate, in target firms, and in domestic firms that are related in some way to target firms. To understand further the main mechanism behind these regularities, we present a stylized model that closely follows Feenstra and Hanson (1997) and 
Feenstra $(2004){ }^{7}$

Consider a world economy that consists of two countries: Home and Foreign. We will denote all variables for the foreign country with $*$ and will assume that Home is a much larger economy than Foreign. Each country has endowments of capital $\left(K, K^{*}\right)$ with returns $r$ and $r^{*}$, unskilled labor $\left(L, L^{*}\right)$ with wage rates $w$ and $w^{*}$, and skilled labor $\left(H, H^{*}\right)$ with wage rates $\alpha w$ and $\alpha^{*} w^{*}$, where $\alpha$ denotes skill premium. We assume that capital and skilled labor are relatively scarce in the South, and therefore $r^{*}>r$ and $\alpha^{*}>\alpha$. In addition, skilled labor requires extra compensation, and therefore $\alpha>1$.

Each country produces a continuum of intermediate goods $z$ that are used to assemble the final consumption good. The production of intermediate goods uses capital, and both skilled and unskilled labor. Intermediate goods are ranked from 0 to 1 in order of increasing ratio of skilled to unskilled labor needed to produce them. Thus, $a_{H}(z) / a_{L}(z)$, where $a_{H}$ and $a_{L}$ are skilled and unskilled labor inputs to produce good $z$, is an increasing function of $z$. Given this ranking and the fact that $\alpha>1$, the cost of producing intermediate goods $C$ will also be increasing in $z$ and the increase will be more pronounced in the Foreign economy because $\alpha^{*}>\alpha$. The left panel of Figure 1 presents the distribution of global production with trade in intermediate goods - allocating production in a country with lower cost. We find that goods $\left[0, z^{*}\right]$ will be produced in Foreign country, while goods $\left[z^{*}, 1\right]$ will be produced in Home country. As a result, in an initial equilibrium, we will observe higher skill premium, higher ratio of skilled to non-skilled employment, and higher average wages in the Home economy than in Foreign.

Now consider the effect of direct investment from Home to Foreign in the form of capital on the Foreign economy. Since we assumed Home economy is much larger, this capital transfer will lower $r^{*}$ but will not have much effect on $r .{ }^{8}$ With lower $r^{*}$, the total cost of producing every intermediate good in Foreign country will fall, as illustrated on the right panel of Figure 1. As a result, it will now be cost-effective to produce a larger set of goods in Foreign economy, that is, $z^{*}$ will increase.

\footnotetext{
${ }^{7}$ Here we omit derivations and technical details, which can be found in the original sources. In addition, in the Appendix we present the extension of the model to endogenous supply of skilled labor.

${ }^{8}$ Even if we allow for an increase in $r$, the effects will be qualitatively the same.
} 

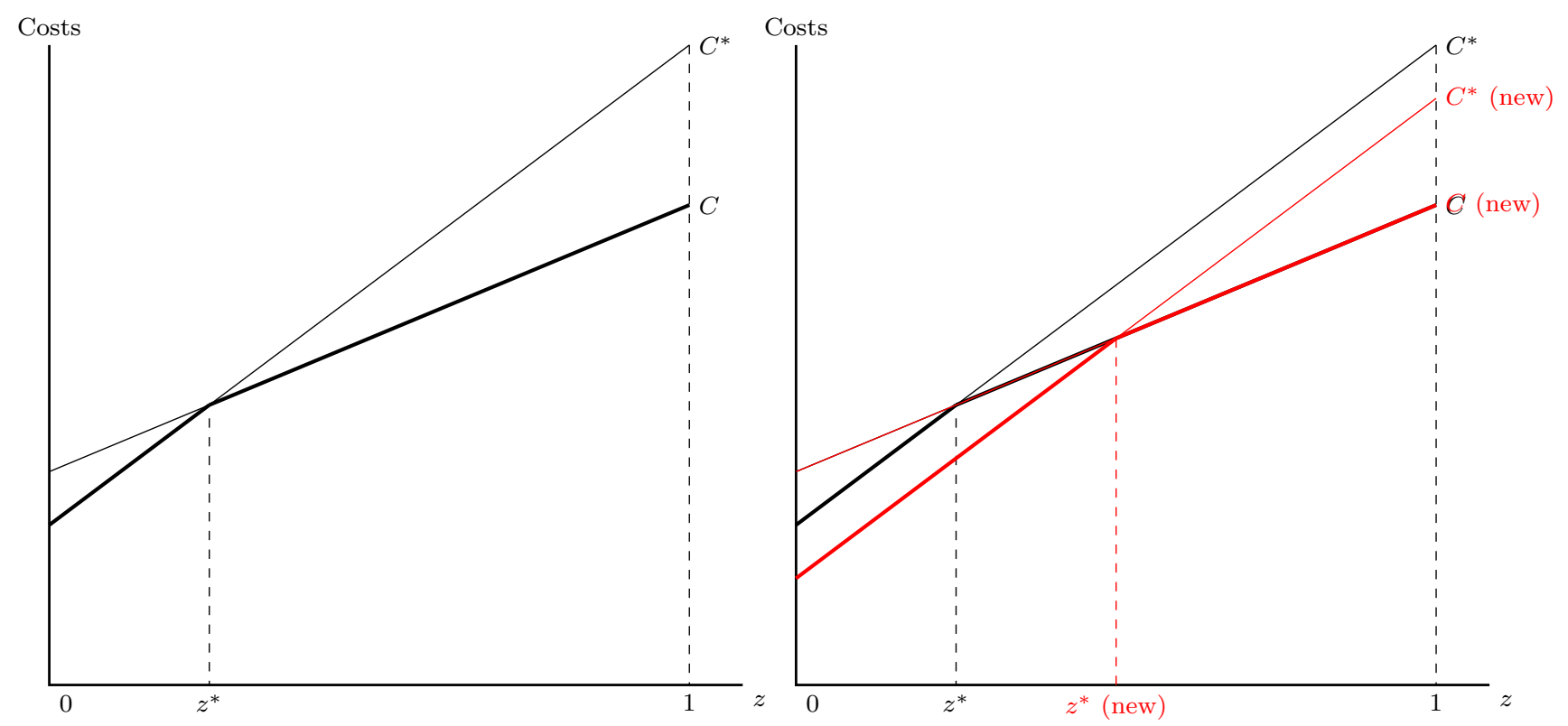

Figure 1: Costs of producing intermediate goods before and after FDI.

This has a number of effects. First, more goods are now produced in Foreign country, meaning an increase in overall demand for labor and higher wages. Second, the new goods produced in Foreign country are more skill-intensive, so demand for skilled labor in Foreign economy increases.

An increased demand for skilled labor will have different effects depending on the relative supply of skilled labor, as illustrated in Figure 2. If the relative supply of skilled labor is elastic as shown in the left panel, that is, if a higher skill premium leads to the movement of workers from unskilled to skilled category, the result of FDI would be an increase in skill premium and also an increase in the share of skilled labor employed (from point A to point B), which in turn leads to a higher average wage. As we discussed previously, movement from an unskilled to a skilled labor force could be costly and time consuming in practice. Therefore, the relative supply of skilled labor is likely to be inelastic, especially if one focuses on the short run. The right panel of Figure 2 shows that, in this case, there will be a larger increase in the skill premium, but the composition of the labor force will not be affected (from point $\mathrm{C}$ to point $\mathrm{D}$ ). This illustrates that the time horizon of empirical studies needs to be taken into account when analyzing the effect of FDI on employment and wages.

We have shown in this very simple model that FDI in the form of capital transfer will increase employment, average wages, skill premium, and wage inequality in the target economy. In the longer 

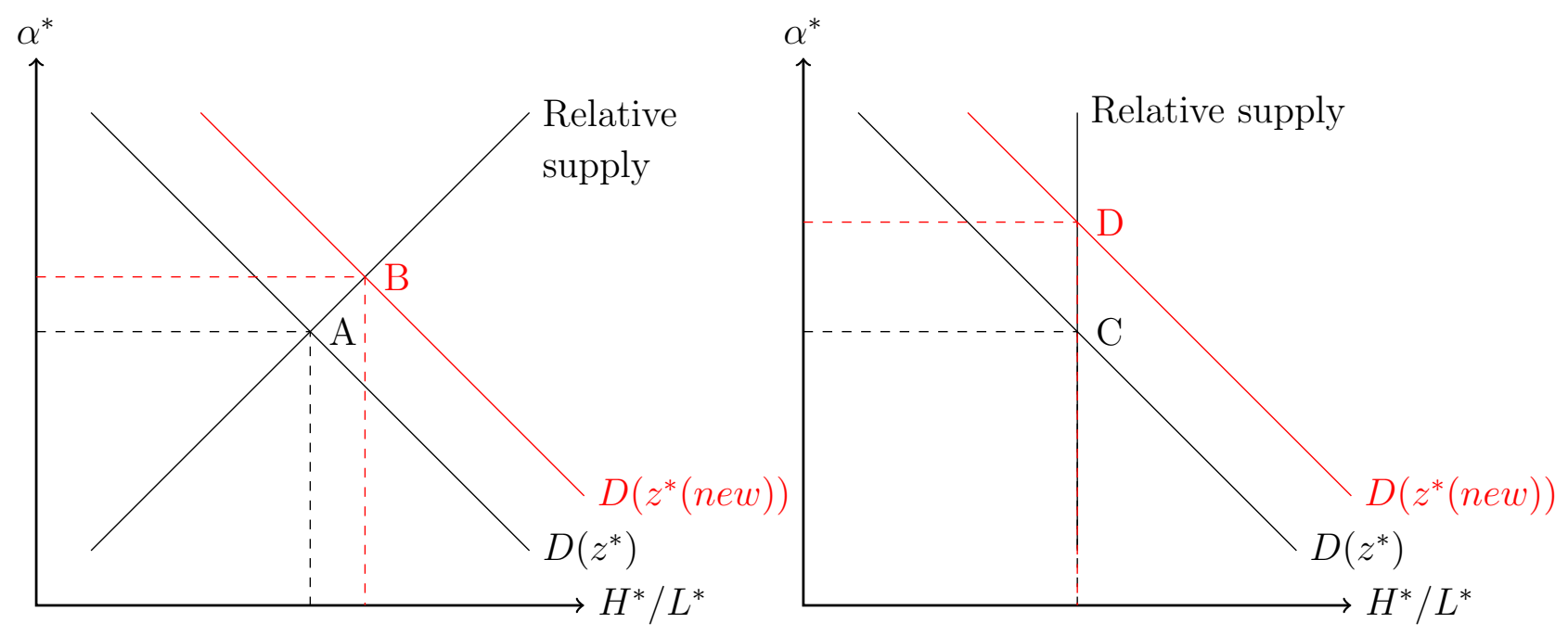

Figure 2: Relative demand for skilled labor, supply elasticity, and skill premium.

run it will also increase the share of skilled labor. One can show that technology transfer will have similar effects by increasing productivity and reducing the cost of production in a similar way as capital transfer. All of these effects are consistent with the majority of empirical findings. Moreover, in the Appendix we present the extension of the model, which endogenizes the acquisition of skill by workers through costly education. This model extension shows, in addition, that FDI is likely to have a smaller impact on wage inequality in regions with better absorptive capacity, which tend to be regions with better access to education, such as more developed host countries. This prediction is consistent with differences in empirical findings for developed and developing countries in the literature we surveyed.

Of course, this model does not capture many subtle aspects of the FDI and differences between developed and developing economies, but it does provide a good starting point for thinking about the mechanisms by which FDI affects labor market outcomes in recipient countries. Moreover, the model can also be used to analyze the impact on the source country, although this is beyond the scope of this paper. 


\section{Conclusion}

Overall, it appears, FDI has positive effects on host countries' labor markets. Wages increase and so do productivity and the skill level of the labor force. Even though some lower-skilled workers may experience adverse effects and some domestic firms may suffer competition pressure in terms of the availability of skilled labor, most of the literature suggests that labor conditions improve as a result of FDI. The increase in inequality that results from disproportional growth of demand for skilled labor may induce the labor force to seek education and training. What, then, are the policy implications of these findings?

First we note that the majority of positive effects observed are direct effects on target firms. Insofar as the managers of these firms take into account these effects for their business planning, no government intervention is needed to obtain the optimal amount of FDI. On the other hand, some labor productivity spillovers and higher wages are observed in domestic firms. If these spillovers are driven by actual productivity improvements in domestic firms, they might justify policies that encourage foreign investments. However, if these developments are due to increased pressure on the labor market, leading to the loss of skilled labor by domestic firms, barriers to FDI might be justified.

When it comes to labor markets income inequality is usually another major concern. As the literature shows, FDI increases this inequality. The mechanism by which FDI affects inequality, however, has to do with other shortcomings in the host country that could be addressed directly and don't justify restrictions on FDI. If there is a shortage of skilled labor and FDI generates a surplus of unskilled labor, investment in training programs and advanced education might be more effective.

We find that there is still insufficient evidence on spillover effects of FDI on labor market conditions faced by domestic firms, which is very important for formulating policy recommendations and for a more complete understanding of the mechanisms at work. For these reasons we hope to see further work developing in this direction. 


\section{A Elastic Supply of Skills}

Assume Foreign country is populated with a mass of people $M$, with innate ability a following distribution $F(a)$ with support $\left[a_{m i n},+\infty\right]$. Based on innate ability, each individual decides whether to work as skilled or unskilled labor. To become a skilled worker, one has to receive education which reduces utility by $\delta(a)$, which varies by innate ability a. Following Becker's human capital theory, we assume

$$
\delta^{\prime}(a)<0, \lim _{a \rightarrow+\infty} \delta(a)=1 \text { and } \delta\left(a_{m i n}\right)=\delta_{0}>1
$$

The above assumptions imply that studying is costly for everybody, but it is less costly for people with higher ability. This implies that people with higher ability have a comparative advantage in supplying skilled labor. There exists a threshold ability at which an individual is indifferent between supplying skilled and unskilled labor, which we denote as $\bar{a}$. Then we must have

$$
w_{H} / \delta(\bar{a})=w_{L}, \text { or } \alpha=\delta(\bar{a})
$$

The relative supply of skills can be expressed as a decreasing function of $\bar{a}$,

$$
\frac{H^{s}}{L^{s}}=\frac{1-F(\bar{a})}{F(\bar{a})} .
$$

Combining $A(2)$ and $A(3)$, we can express the skill supply curve as

$$
\frac{H^{s}}{L^{s}}=\frac{1-F\left(\delta^{-1}(\alpha)\right)}{F\left(\delta^{-1}(\alpha)\right)} .
$$

It can be shown that $\frac{d \alpha}{d\left(H^{s} / L^{s}\right)}>0$. Specifically, if we assume $F$ follows a Pareto distribution, i.e., $F(a)=1-\left(a_{\min } / a\right)^{k}$ and $\delta(a)=1+a^{-\gamma}$, the relative supply of skills is given by

$$
\frac{H^{s}}{L^{s}}=\frac{a_{\min }^{-k}}{a_{\min }^{-k}-(\alpha-1)^{\frac{k}{\gamma}}}-1,
$$


where $k$ measures the dispersion of talent and $\gamma$ measures sensitivity of education cost to ability. ${ }^{9}$ This equation implies that FDI will have a stronger employment effect and smaller wage effect if the host country has a smaller dispersion of talents (smaller $k$ ), higher average quality of citizens (bigger $a_{\text {min }}$ ), and larger sensitivity of education cost with respect to ability (larger $\gamma$ ), which could be interpreted as sophistication of its educational system.

This is consistent with recent empirical findings that the effects of FDI on inequality depend on absorptive capacity of host regions, which is usually measured as the distance to a technological frontier. Specifically, FDI will have a smaller effect on skill premium and therefore on income inequality in regions with higher absorptive capacity.

\footnotetext{
${ }^{9}$ Larger value of $\gamma$ implies more inelastic supply of skills.
} 


\section{References}

B. Aitken, A. Harrison, and R. E. Lipsey. Wages and foreign ownership a comparative study of mexico, venezuela, and the united states. Journal of International Economics, 40(3-4):345-371, 1996.

R. Almeida. The labor market effects of foreign owned firms. Journal of International Economics, 72(1):75-96, 2007.

R. Bandick and P. Karpaty. Employment effects of foreign acquisition. International Review of Economics \& Finance, 20(2):211-224, 2011.

F. Barry, H. Görg, and E. Strobl. Foreign direct investment and wages in domestic firms in ireland: Productivity spillovers versus labour market crowding out. International Journal of the Economics of Business, pages 67-84, 2005.

B. A. Blonigen and M. J. Slaughter. Foreign-affiliate activity and u.s. skill upgrading. Review of Economics and Statistics, 83(2):362-76, May 2001.

Z. Chen, Y. Ge, and H. Lai. Foreign direct investment and wage inequality: Evidence from china. World Development, 39(8):1322-1332, 2011.

L. K. Cheng and Y. K. Kwan. What are the determinants of the location of foreign direct investment? the chinese experience. Journal of International Economics, 51:379-400, 2000.

M. J. Conyon, S. Girma, S. Thompson, and P. W. Wright. The productivity and wage effects of foreign acquisition in the united kingdom. Journal of Industrial Economics, 50(50):85-102, 2002.

M. Dinga and D. Mnich. The impact of territorially concentrated fdi on local labor markets: Evidence from the czech republic . Labour Economics, 17(2):354-367, 2010.

N. Driffield and K. Taylor. Fdi and the labour market: a review of the evidence and policy implications. Oxford Review of Economic Policy, 16(3):90-103, 2000. 
R. C. Feenstra. Advanced International Trade: Theory and Evidence. Princeton University Press, Princeton, New Jersey, 2004.

R. C. Feenstra and G. H. Hanson. Foreign direct investment and relative wages: Evidence from mexico's maquiladoras. Journal of International Economics, 42(3-4):371-393, 1997.

P. Figini and H. Görg. Multinational companies and wage inequality in the host country: The case of ireland. Open Access Publications from Kiel Institute for the World Economy, 135(4):594-612, 1999.

P. Figini and H. GöRg. Does foreign direct investment affect wage inequality? an empirical investigation. World Economy, 34(9):1455-1475, 2011.

S. Girma and H. Görg. Evaluating the foreign ownership wage premium using a difference-indifferences matching approach. Ssrn Electronic Journal, 72(1):97-112, 2007.

G. Hale and C. Long. Did foreign direct investment put an upward pressure on wages in china? IMF Economic Review, 59(3):404-430, 2011.

A. E. Harrison, J. Scorse, et al. Do foreign-owned firms pay more? Evidence from the Indonesian manufacturing sector 1990-99. International Labour Office, 2005.

F. Heyman, F. Sjöholm, and P. G. Tingvall. Is there really a foreign ownership wage premium? evidence from matched employer-employee data. Journal of International Economics, 73(2):355$376,2007$.

A. Hijzen, P. S. Martins, T. Schank, and R. Upward. Foreign-owned firms around the world: A comparative analysis of wages and employment at the micro-level . European Economic Review, 60(2):170-188, 2013.

K. Huttunen. The effect of foreign acquisition on employment and wages: Evidence from finnish establishments. Review of Economics 65 Statistics, 89(3):497-509, 2007. 
C. Jude and M. I. P. Silaghi. Employment effects of foreign direct investment: New evidence from central and eastern european countries. International Economics, 145:32-49, 2015.

S. C. Lin, D. H. Kim, and Y. C. Wu. Foreign direct investment and income inequality: Human capital matters. Journal of Regional Science, 53(5):874-896, 2013.

R. E. Lipsey and F. Sjöholm. Foreign direct investment, education and wages in indonesian manufacturing. Journal of Development Economics, 73(1):415-422, 2004a.

R. E. Lipsey and F. Sjöholm. Fdi and wage spillovers in indonesian manufacturing. Review of World Economics, 140(2):321-332, 2004b.

T. H. Moran. Harnessing Foreign Direct Investment for Development: Policies for Developed and Developing Countries. Center for Global Development, Washington DC, 2006.

B. R. Moulton. An illustration of a pitfall in estimating the effects of aggregate variables on micro units. The Review of Economics and Statistics, 72(2):334-338, May 1990.

A. Peluffo. Foreign direct investment, productivity, demand for skilled labour and wage inequality: An analysis of uruguay. World Economy, 38(6):962-983, 2015.

R. Pittiglio, F. Reganati, and E. Sica. Do multinational enterprises push up the wages of domestic firms in the italian manufacturing sector? The Manchester School, 83(3):346-378, 2015.

F. Sjöholm and R. E. Lipsey. Foreign firms and indonesian manufacturing wages: An analysis with panel data. Economic Development and Cultural Change, 55(1):201-221, 2006.

Q. Sun, W. Tong, and Q. Yu. Determinants of foreign direct investment across china. Journal of International Money and Finance, 21:79-113, 2002.

K. Sune, L. Nannan, S. Fredrik, and H. Ping. Foreign firms and chinese employment. World Economy, 32(1):178-201, 2009. 
K. Taylor and N. Driffield. Wage inequality and the role of multinationals: evidence from uk panel data. Labour Economics, 12(2):223-249, 2005.

A. Waldkirch and P. Nunnenkamp. Employment effects of fdi in mexico's non-maquiladora manufacturing. Journal of Development Studies, 45(7):1165-1183, 2009.

J. Y. Wu and C. C. Hsu. Foreign direct investment and income inequality: Does the relationship vary with absorptive capacity? Economic Modelling, 29(6):2183-2189, 2012. 